Article

\title{
Antioxidant, Antimicrobial, and Other Biological Properties of Pompia Juice
}

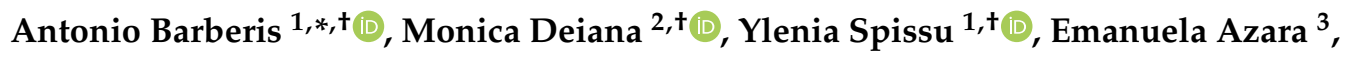 \\ Angela Fadda ${ }^{1}$, Pier Andrea Serra ${ }^{1,4}$, Guy D’hallewin ${ }^{1}$, Marina Pisano ${ }^{3}{ }^{\circledR}$, Gabriele Serreli ${ }^{2}$, \\ Germano Orrù ${ }^{1,5}$ (D) Alessandra Scano ${ }^{5}$, Daniela Steri ${ }^{6}$ and Enrico Sanjust ${ }^{2, *(D)}$ \\ 1 Institute of Sciences of Food Production, National Research Council, 07100 Sassari, Italy; \\ yspissu82@gmail.com (Y.S.); angela.fadda@cnr.it (A.F.); paserra@uniss.it (P.A.S.); \\ guy.dhallewin@cnr.it (G.D.); orru@unica.it (G.O.) \\ 2 Department of Biomedical Sciences, University of Cagliari, 09100 Cagliari, Italy; mdeiana@unica.it (M.D.); \\ gabrieleserreli@hotmail.it (G.S.) \\ 3 Institute of Biomolecular Chemistry, National Research Council, 07100 Sassari, Italy; \\ emanuelagigliola.azara@cnr.it (E.A.); marina.pisano@cnr.it (M.P.) \\ 4 Department of Medical, Surgical and Experimental Medicine, University of Sassari, 07100 Sassari, Italy \\ 5 Department of Surgical Sciences, Molecular Biology Service, University of Cagliari, 09100 Cagliari, Italy; \\ alessandrascano@libero.it \\ 6 PPD Pharmaceutical Industries, 37121 Verona, Italy; daniela.steri@googlemail.com \\ * Correspondence: antonio.barberis@cnr.it (A.B.); sanjust@unica.it (E.S.); Tel.: +39-079-2841710 (A.B.) \\ + These authors contributed equally to this work.
}

Received: 15 June 2020; Accepted: 9 July 2020; Published: 13 July 2020

\begin{abstract}
Pompia is a Citrus species belonging to Sardinian endemic biodiversity. Health benefits were attributed to its flavedo rind extracts and essential oils while the juice qualities have never been investigated. In this paper, the antioxidant, antimicrobial, and other biological properties of Pompia juice were studied. A combined LCMS/electrochemical/biological approach was used to clarify a still debated phylogeny of this species and to explain the role of its juice phenolic compounds. A closer phylogenetic relationship with lemon and citron, rather than oranges was suggested. Sensors-based electrochemical measures, together with LCMS qualitative and quantitative analyses, revealed a high contribution of ascorbic acid and phenolics with low redox potential, isorhamnetin 3-O-rutinoside, diosmin, and diosmetin 6,8-diglucoside, to antioxidant capacity. The biological assays demonstrated a marked effect of low concentration of Pompia juice against reactive oxygen species (ROS) starting from $50 \mu \mathrm{g} \mathrm{mL}^{-1}$, and a moderate capacity to reduce ROS damages on cell membrane. Treatments with Pompia juice also resulted in a significant reduction (20\%) of the metabolic activity of SW48 colon cancer cells. Lastly, MIC, MBC, and MBIC antimicrobial assays demonstrated that Pompia and lemon juices have inhibitory and antibiofilm effects against the pathogenic bacteria Pseudomonas aeruginosa, Streptococcus aureus, and Enterococcus faecalis.
\end{abstract}

Keywords: Pompia juice; phenolics; chemical characterization; antioxidant activity; antimicrobialantibiofilm activity; colon cancer cells

\section{Introduction}

Citrus species are extensively cultivated all over the world because of their high organoleptic and nutritional value. They are eaten as fresh or consumed as jams, candies, juices, and ingredients for sweets and desserts. Being rich in vitamin $C$ and phenolics, especially flavonoids [1], the attention of the literature to citrus fruits antioxidant properties has considerably increased because of the evidence 
of a correlation between the intake of citrus fruits and a reduced risk to develop degenerative diseases, neurological and cardiovascular disorders, obesity, diabetes, and certain types of cancer [2-5].

The antioxidant activity has been widely studied in Citrus species and hundreds of papers showed that ascorbic acid (AA) and polyphenols are primarily responsible for this [6]. The combined electrochemical and mass-spectrometry approach suggested a preeminent role of vitamin $C$ as antioxidant and a much more complex function of flavonoids and anthocyanins [7]. Phenolics from citrus fruits own important qualities, with a large number of beneficial effects on human health. Bergamot juice acts as anti-inflammatory agent in lipopolysaccharide-treated murine macrophages because of its high content of flavonoids [8], and blocks the proinflammatory actions induced by interferon-gamma and histamine on human keratinocytes [9]. Hydro-alcoholic extracts of C. aurantium peel significantly inhibited histamine- and dextran-induced edema in rats in a concentration-dependent manner, providing evidence of a possible therapeutic use [10]. C. limon therapeutic action has been studied by in vitro assays of ethanol extracts against a panel of microbes implicated in skin diseases [11], while the juices of $C$. hystrix and C. maxima were investigated for their anti-diabetic, cholinesterase, and tyrosinase inhibitory potential [12]. Studies on anti-tumor effects of citrus juice bioactive compounds were also performed: a chemo-preventive activity on neuroblastoma and hepatocellular carcinoma was attributed to phenolics of bergamot juice [13-15] and to flavonoids of Mexican lime juice on pancreatic cancer [16].

Among Citrus species, Citrus limon var. pompia Camarda var. nova [17], previously classified as Citrus $x$ monstruosa [18], is a particular citron-like tree locally known as "Pompia." It is an endemic species cultivated in Sardinia, primarily along the north-eastern coast of the Italian island. The tree has an ancient origin $[19,20]$ and its cultivation has recently known a revival because of the use of fruit rind in Sardinian traditional sweets, classified as Slow Food [21]. For centuries, the local tradition has attributed to Pompia flavedo and its essential oils beneficial properties on health, even though no scientific evidence was available. Only recently, a chemical characterization of Pompia rind compounds has been carried out in the view of their incorporation in vesicular systems for skin delivery [22] and for the protection of oral cavity [23], while Pompia leaf essential oils were characterized to investigate the antimicrobial activity against food-related microorganisms [24]. Other peculiarities of this fruit are the characteristic flavor, which somewhat resembles that of lemon, the very thick albedo and the low quantity of juice, which is characterized by high acidity and low sugar content [18].

As far as we know, no information is available on the properties of Pompia juice. Therefore, the aim of this work is to investigate its putative antioxidant and antimicrobial capacity, and antiproliferative activity on colon cancer cells, in comparison with the well-known Lisbon lemon cultivar [25] and some previously studied orange varieties [7]. Once achieved a phenolics characterization, the antioxidant capacity of Pompia juice was measured, and electrochemical analyses, based on a previously developed sensor/biosensor system, were used to distinguish the AA and phenolics contribution to antioxidant activity $[7,26]$. The protective effect against reactive oxygen species (ROS) and enterocyte membrane damage was investigated using differentiated $\mathrm{CaCo}-2$ intestinal cancer cells. Furthermore, with the evidence of the above mentioned antitumoral effects of others Citrus spp., the capacity of low concentration of Pompia juice to affect the metabolic activity of parental undifferentiated CaCo-2 cells and of SW48, both colon cancer cell lines, was studied. Lastly, we investigated the antimicrobial and antibiofilm activity of Pompia juice and the other citrus fruits against Gram-negative and Gram-positive bacterial strains, in comparison with specific antibiotic drugs.

\section{Results and Discussion}

Pompia juice has such organoleptic characteristics that it has traditionally always been considered a waste product of the fruit. The yield is very low $(12.3 \pm 2 \%)$, the $\mathrm{pH}$ is $2.3 \pm 0.5$, the titratable acidity is $6.9 \pm 0.2 \%$ citric acid equivalents, and TSS are $7.2 \pm 0.3^{\circ}$ Brix. The taste is particularly sour and bitter. 


\subsection{Chemical Characterization of Citrus Juices}

The chromatograms of phenolics detected in Pompia, lemon, and orange juices are reported in Figure S1, while the quantification of the most represented compounds (all the phenolics over the LOQ of LCMS system) is in Table 1.

Table 1. Quantification ( $\mathrm{mg} \mathrm{L}^{-1} \pm$ standard deviation) of phenolics in Pompia, lemon (cv Lisbon) and orange juices ( $c v$ Hamlin, Sanguinello and Moro) obtained by LCMS analysis.

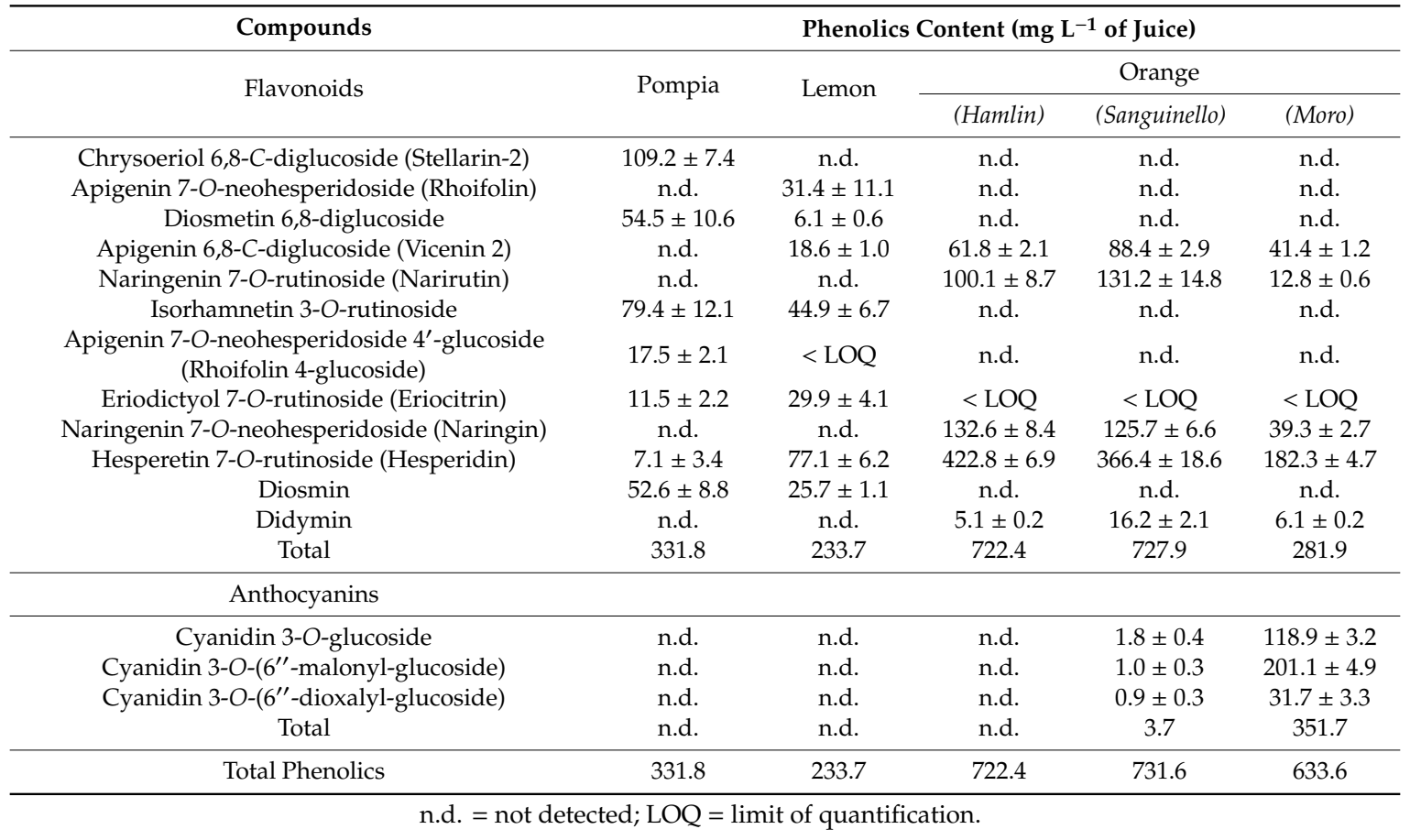

The chromatograms of phenolics detected in Pompia, lemon, and orange juices are reported in Figure S1, together with the complete list of 46 (21 in Pompia, 20 in Lemon, 14 in Hamlin, 14 in Sanguinello and 16 Moro) identified molecules, together with their retention time (RT) (Table S1). Because of the more precise analytical method adopted, this characterization represents a significant upgrade compared to the previous one for the same orange varieties [7]. The higher peak in the Pompia juice ( $\mathrm{RT}=11.15 \mathrm{~min}$ ) is a quinic acid derivative but, since a better characterization of this molecule was not possible, its quantification could not be provided. According to Table 1 and Table S1, the phenolic composition of Pompia juice is more similar to lemon than to the oranges. The most represented flavonoid in the Pompia juice, not detected in the other juices, is the chrysoeriol-6,8-di- $C$-glucoside also known as stellarin-2 $\left(109.2 \mathrm{mg} \mathrm{L}^{-1}\right)$, described for the first time in the juice of the lemon cv Verna [27]. Isorhamnetin-7-rutinoside, diosmetin-6,8-dihexoside, and diosmin (79.4, 54.5, and $52.6 \mathrm{mg} \mathrm{L}^{-1}$ respectively) are also highly represented in Pompia, significantly less in lemon, and are absent in the oranges. Rhoifolin-4-glucoside was also found only in the juice of Pompia, while $31.4 \mathrm{mg}$ $\mathrm{L}^{-1}$ of rhoifolin, the corresponding aglycone, was detected in the lemon juice. Hesperidin, generally responsible for citrus juices cloudiness [28], is the only molecule common to all the juices, found in a very low concentration in Pompia but highly represented in all orange varieties $(422.8,366.4$, and $182.3 \mathrm{mg} \mathrm{L}^{-1}$ in Hamlin, Sanguinello, and Moro respectively). No anthocyanins were found in the Pompia juice. As previously said, Pompia has been considered a citrus variety belonging to C. limon species [17], but there are not definitive conclusions on this taxonomy and the most recent studies, based on karyological [20] and genetic [19] analyses suggested that Pompia is a cross between sour orange and citron. The provided phenolics characterization of Pompia juice adds elements but cannot solve this puzzle since many molecules identified in Pompia were also found in lemon juice, while 
some are typical of citron (Citrus medica L.) [29,30], and some others characterize bergamot [13,28], another species of still uncertain botanical origin, defined as a hybrid between sour orange and lemon [15]. On the other hand, similarities can be found between Pompia [24] and bergamot [31] essential oil composition.

\subsection{Antioxidant Capacity and AA Content Determination in Citrus Juices}

Table 2 shows the antioxidant capacity (Table 2A) of different juices, obtained with the SB, DPPH, and ABTS methods. It also provides data concerning ascorbic acid content (Table 2B) measured by SB, titrimetric, and HPLC methods.

Table 2. (2A) Antioxidant capacity (ascorbic acid equivalents) as determined by SB electrochemical system at $+500 \mathrm{mV}$, by DPPH (EPR) and by ABTS (spectrophotometric) reference methods, in the juices of Pompia, lemon ( $c v$ Lisbon), and oranges ( $c v$ Hamlin, Sanguinello, and Moro). AA and phenolics contributions to antioxidant activity were also provided by SB system. (2B) Ascorbic acid content $\left(\mathrm{mg} \mathrm{L}^{-1}\right)$ as determined by SB system at $+500 \mathrm{mV}$, titrimetric, and HPLC methods in the juices of Pompia, lemon ( $c v$ Lisbon), and oranges ( $c v$ Hamlin, Sanguinello and Moro).

\begin{tabular}{|c|c|c|c|c|c|c|}
\hline \multicolumn{7}{|c|}{ (2A)-Antioxidant Capacity (mmoL Equivalents of AA L ${ }^{-1}$ of Juice) } \\
\hline \multicolumn{2}{|c|}{ Method of Detection } & Pompia & Lemon (Lisbon) & $\begin{array}{l}\text { Orange } \\
\text { (Hamlin) }\end{array}$ & $\begin{array}{c}\text { Orange } \\
\text { (Sanguinello) }\end{array}$ & $\begin{array}{l}\text { Orange } \\
\text { (Moro) }\end{array}$ \\
\hline \multirow[b]{2}{*}{ SB } & Total & $4.98 \mathrm{~b}(\mathrm{a})$ & $4.59 \mathrm{~b}(\mathrm{a})$ & $4.14 \mathrm{c}(\mathrm{b})$ & $3.89 \mathrm{~b}(\mathrm{c})$ & $3.36 \mathrm{~b}(\mathrm{~d})$ \\
\hline & AA contribution & $4.41(\mathrm{a})$ & $4.04(\mathrm{~b})$ & $3.99(b)$ & $3.31(\mathrm{c})$ & $2.47(\mathrm{~d})$ \\
\hline ABTS & Total & 5.39 a (a) & $5.09 \mathrm{a}(\mathrm{ab})$ & 4.83 a (b) & $4.44 \mathrm{a}(\mathrm{c})$ & $4.12 \mathrm{a}(\mathrm{c})$ \\
\hline
\end{tabular}

\begin{tabular}{|c|c|c|c|}
\hline \multicolumn{4}{|c|}{ (2B)-AA Content (mg L ${ }^{-1}$ of Juice) } \\
\hline Citrus Species & SB & Titrimetric & HPLC \\
\hline Pompia & $582.3 \mathrm{a}(\mathrm{a})$ & $545.2 \mathrm{a}(\mathrm{b})$ & $577.5 \mathrm{a}(\mathrm{a})$ \\
\hline Lemon $c v$ Lisbon & $528.6 \mathrm{~b}(\mathrm{a})$ & $496.0 \mathrm{~b}(\mathrm{a})$ & $507.7 \mathrm{~b}(\mathrm{a})$ \\
\hline Orange $c v$ Hamlin & 582.0 a (a) & 5654 a (a) & 574.4 a (a) \\
\hline Orange $c v$ Moro & 442.7 c (a) & n.d. & $431.2 \mathrm{c}(\mathrm{a})$ \\
\hline
\end{tabular}

Means in columns followed by unlike letters differ significantly by Fisher's least significant difference (LSD) procedure, $p \leq 0.05$. Means in rows followed by (unlike letters) differ significantly by Fisher's least significant difference (LSD) procedure, $p \leq 0.05$. n.d.= not detectable.

According to SB, Pompia and lemon showed similar antioxidant capacity (4.98 and $4.59 \mathrm{mmoL}$ equivalents of AA $L^{-1}$ of juice respectively), higher than Hamlin, the blond orange variety, Sanguinello and Moro (Table 2A). Similar trends were obtained with the three methods of analysis, even though DPPH, and especially ABTS, showed values statistically higher than SB for the same samples. This difference was expected since the SB system oxidized only the molecules with a redox potential $\leq$ $+500 \mathrm{mV}$, highlighting the role of AA and phenolics with low redox potential, those which act first as radical scavengers. Differently, DPPH and ABTS methods consider a wider pool of compounds, consistent with a reduction potential of $+680 \mathrm{mV}$ [32]. To better understand the relationship between total phenolic content and the phenolic contribution to the antioxidant activity, we correlated first the total phenols (determined with LCMS from Table 1) with the total antioxidant activity (measured by the three systems, from Table 2), and then the total phenolics with the phenolic contribution measured by the sensor (from Table 2). In all the cases we did not find any significant correlation, as in many other papers in the literature.

The difference in antioxidant capacity among species cannot be simply attributed to a different content of total phenolics, but should be ascribed to AA content and to the quality of phenolic 
compounds. Only the redox potential is indication of their reducing power [33] so, what matters is the class of molecules to which they belong and their relative quantity in the juice. The AA oxidation occurs at a very low potential, close to zero $\mathrm{mV}[7,26,34]$. The AA content in Pompia is higher than in lemon and oranges, so its contribution to antioxidant capacity is decisive (Table 2B).

In Figure 1, the cyclic voltammetric patterns recorded for Pompia and lemon (A), and for oranges (B), revealed that the oxidation in juices started from +80 to $+150 \mathrm{mV}$, a value mainly consistent with the AA redox potential [26]. The voltammograms had similar shapes but the currents, recorded at $+500 \mathrm{mV}$, by different juices, varied from 1 to $2 \mu \mathrm{A}$. These differences should be attributed to the activity of phenolics with different redox potential. According to CVs of some of the most represented compounds, the antioxidant activity of Pompia is principally due to isorhamnetin 3-O-rutinoside (oxidation starts at $+80 \mathrm{mV}$ ), diosmin and diosmetin 6,8-diglucoside (oxidation starts at $+400 \mathrm{mV}$ and $+460 \mathrm{mV}$ respectively) (Figures S2, S3, and S4). Unfortunately, the standard of one of the most represented compounds in the Pompia juice, the Stellarin-2, was not available, so we can only rely on the literature to speculate on its antioxidant capacity. This C-glucoside, previously identified in other citrus species $[27,28,35]$ was found in high concentration in Pompia juice. Based on these studies, Stellarin-2, as well as similar flavonoid derivatives, contributes to the reducing ability bearing a double bond at 2.3 position of the $C$-ring. Unfortunately, in the absence of a standard, we have not been able to determine the redox potential of this molecule nor, consequently, its specific contribution to antioxidant activity.
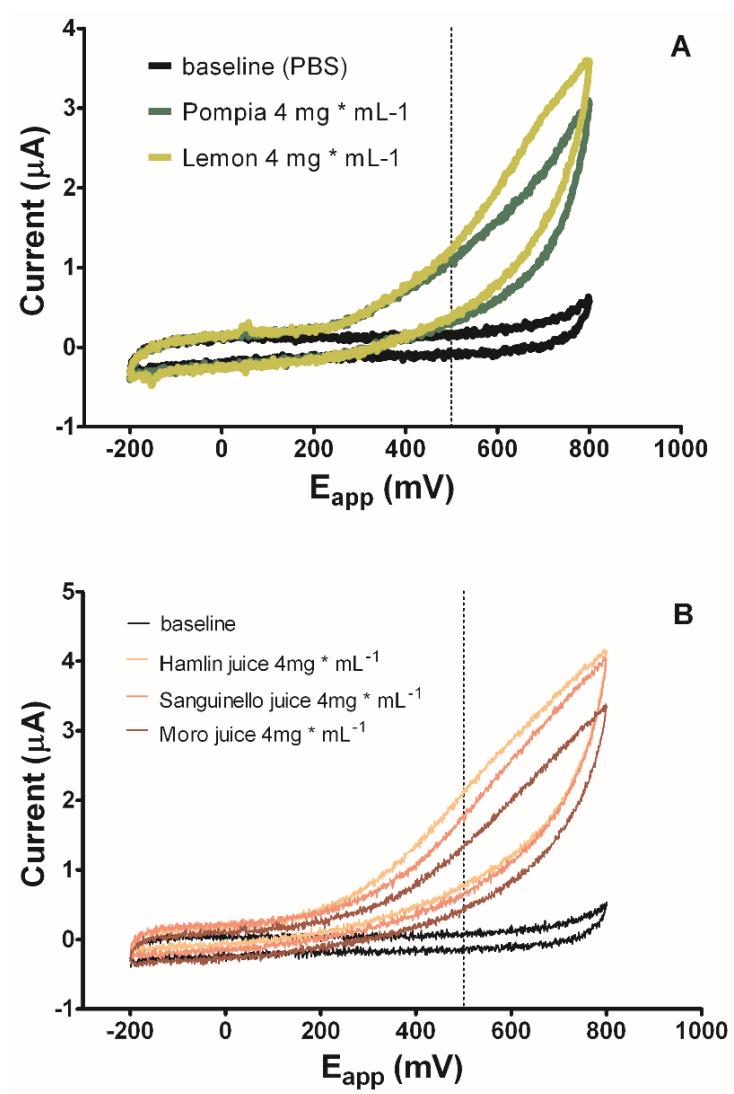

Figure 1. Cyclic voltammetry, with a scanned potential range $\left(E_{a p p}\right)$ comprised between $-200 \mathrm{mV}$ and $+800 \mathrm{mV}$ vs. carbon pseudoreference, in the absence (PBS black line) and in the presence of $4 \mathrm{mg} \mathrm{mL}^{-1}$ of Pompia (green line) and lemon (yellow line) juices (A), and in the absence (PBS black line) and in the presence of $4 \mathrm{mg} \mathrm{mL}^{-1}$ of Hamlin (yellow line), Sanguinello (orange line), and Moro (brown line) juices (B).

Lemon juice owes its antioxidant capacity mainly to AA, isorhamnetin 3-O-rutinoside, and hesperidin (oxidation starts at $+370 \mathrm{mV}$ ). Orange juices have deeply different phenolics composition 
in comparison to Pompia and lemon, and their antioxidant capacity was flesh color dependent: $95 \%$ of flavonoids in Hamlin, Sanguinello, and Moro is represented by hesperidin and narirutin which relatively contribute to antioxidant capacity being oxidized starting from $+370 \mathrm{mV}$ and $+520 \mathrm{mV}$, with oxidation peaks at $+680 \mathrm{mV}$ and $+820 \mathrm{mV}$, respectively $[7,26]$. The polyphenols of Sanguinello and Moro contribute $15 \%$ and $26 \%$, respectively, to antioxidant capacity, although the phenolics content of Sanguinello is greater than Moro. Moro contains a high level of anthocyanins (especially cyanidins whose oxidation begins at about $+280 \mathrm{mV}$ and have redox peaks at about $+400 \mathrm{mV}$ [26], which oxidize to a lower potential than Sanguinello flavonoids, hesperidin, narirutin $(>600 \mathrm{mV})$, and naringin $(+520 \mathrm{mV})$. It has already been shown that the most of organic acids, like citric acid [34] or quinic acid (Figure S5) did not give any contribution to antioxidant capacity.

\subsection{Protective Effect of Pompia and Other Citrus Juices Against ROS and Enterocytes Membrane Damage}

The ability of the juices to exert an antioxidant action was further tested in a more biologically relevant experimental system as the cell cultures. Differentiated Caco- 2 cells were chosen as model of human enterocytes. Control experiments were first carried out to assess a potential juice cytotoxicity, but cell viability remained unchanged in the presence of all the tested juices, compared to untreated cells $\left(100 \%\right.$ of viability), in the concentration range of $10-500 \mu \mathrm{g} \mathrm{mL}^{-1}$ (Figure S6). Then, the potential protective effect of the juices against $\mathrm{TBH}$-induced oxidative damage in $\mathrm{CaCo}-2$ cell monolayers was investigated (Figure 2A). A highly significant steep increase of ROS production was caused by $2.5 \mathrm{mM}$ $\mathrm{TBH}$, in comparison with the untreated cells (control), starting from 15 min of incubation. TBH originates ROS in the reaction mixture that catalyze the peroxidation of membrane lipids [36]. In the presence of the juices, ROS production significantly decreased starting from $50 \mu \mathrm{g} \mathrm{mL}{ }^{-1}$ in comparison with positive control (TBH $2.5 \mathrm{mM}$ alone), and gradually lowered as the juice concentrations grew; at $500 \mu \mathrm{g} \mathrm{mL}^{-1}$, Pompia and Lemon were able to bring the ROS production back to untreated cells value. Orange juices appeared much less effective. The ability of the citrus juices to protect CaCo-2 cell monolayers against TBH oxidative injury was also assessed by measuring malonyldialdehyde (MDA) level after $2 \mathrm{~h}$ of incubation with $2.5 \mathrm{mM}$ TBH, when an advanced peroxidation process had damaged the membrane lipid fraction giving rise to detectable oxidation products as MDA [37]. A 2.5-fold increase of MDA level compared with untreated cells (control) was observed in the culture medium of TBH-treated cells (Figure 2B). Treatment with the juices significantly inhibited MDA production starting from $10 \mu \mathrm{g} \mathrm{mL}^{-1}$ in the case of Sanguinello and lemon and from $50 \mu \mathrm{g} \mathrm{mL}^{-1}$ for all the juices.

These data indicate that Pompia juice is highly effective against ROS production and damaging action, in accordance with the capacity of Pompia rind extracts to prevent oxidative damage, promoting the viability of human keratinocytes and mouse fibroblasts [22]. The antioxidant activity of the Pompia juice in the cell cultures may be related to its radical scavenging ability, as indicated by the sensor, DPPH and ABTS assays. It is noteworthy that Pompia juice, even showing the best scavenging ability in the chemical assays, did not protect the cell membrane more than the other juices. These results further support the opinion that the action of an antioxidant is greatly dependent on the reaction environment and it may be exerted through more than one mechanism in a complex environment such as a biological system. 

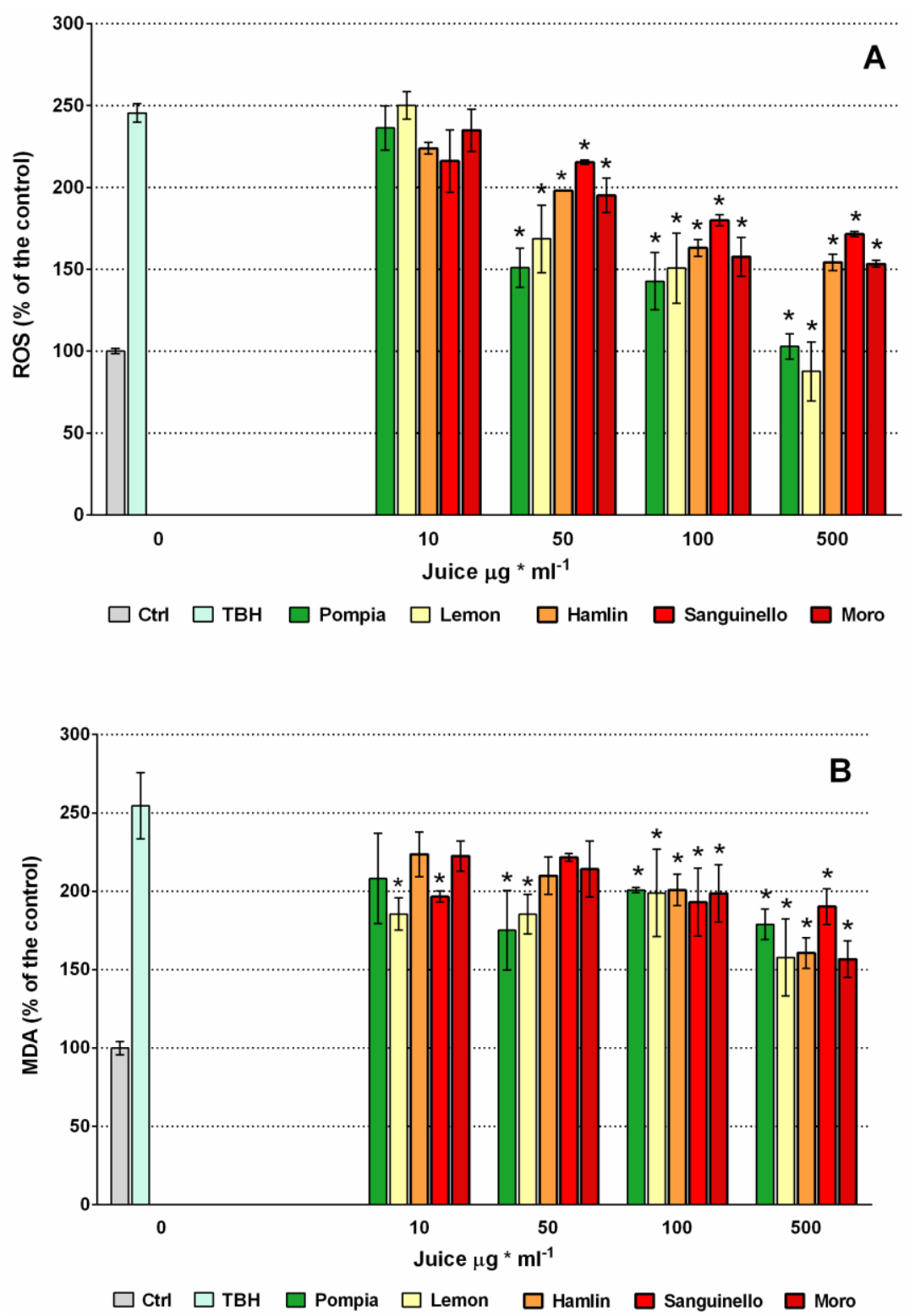

Figure 2. Evaluation of $2.5 \mathrm{mM}$ TBH oxidative stress on differentiated CaCo-2 cell monolayer by determination of intracellular reactive oxygen species (ROS) production (A) and malonyldialdehyde (MDA) level (B), in the absence and in the presence of Pompia and other juices. ${ }^{*} p \leq 0.01 \mathrm{vs.} \mathrm{TBH.}$

\subsection{Influence of Pompia and Lemon Juices on Metabolic Activity of Colon Cancer Cells}

In our study, CVS was used to evaluate $\mathrm{CaCo} 2$ and SW48 cancer cells number when exposed to a preventive treatment with increasing concentration of citrus juices (Figure S7), as this non-enzymatic assay allows the estimation of the number of viable cells, adherent and colonies, since the amount of dye absorbed depends on the total DNA content [38]. Differently, the MTT assay may result in either underestimation or overestimation of the fraction of live cells with the result depending on the type of cells [39].

MTT assay was used instead to assess the metabolic activity linked to mitochondria functional state $[39,40]$. Orange juices of all varieties being totally ineffective on both cell lines, only the results of Pompia and lemon were reported on the graphs. The exposure of $\mathrm{CaCo}-2$ to Pompia and lemon juices did not reduce the number of cancer cells, but a $15-40 \%$ and $10-20 \%$ increase was actually observed for Pompia and lemon juice respectively (Figure S7A). Differently, CaCo-2 metabolic activity (Figure 3) did 
not appear significantly changed by juice treatments, with the exception of a reduction of less than $10 \%$ and of $20 \%$ at $500 \mu \mathrm{g} \mathrm{mL}^{-1}$, for Pompia and lemon respectively (Figure 3A).
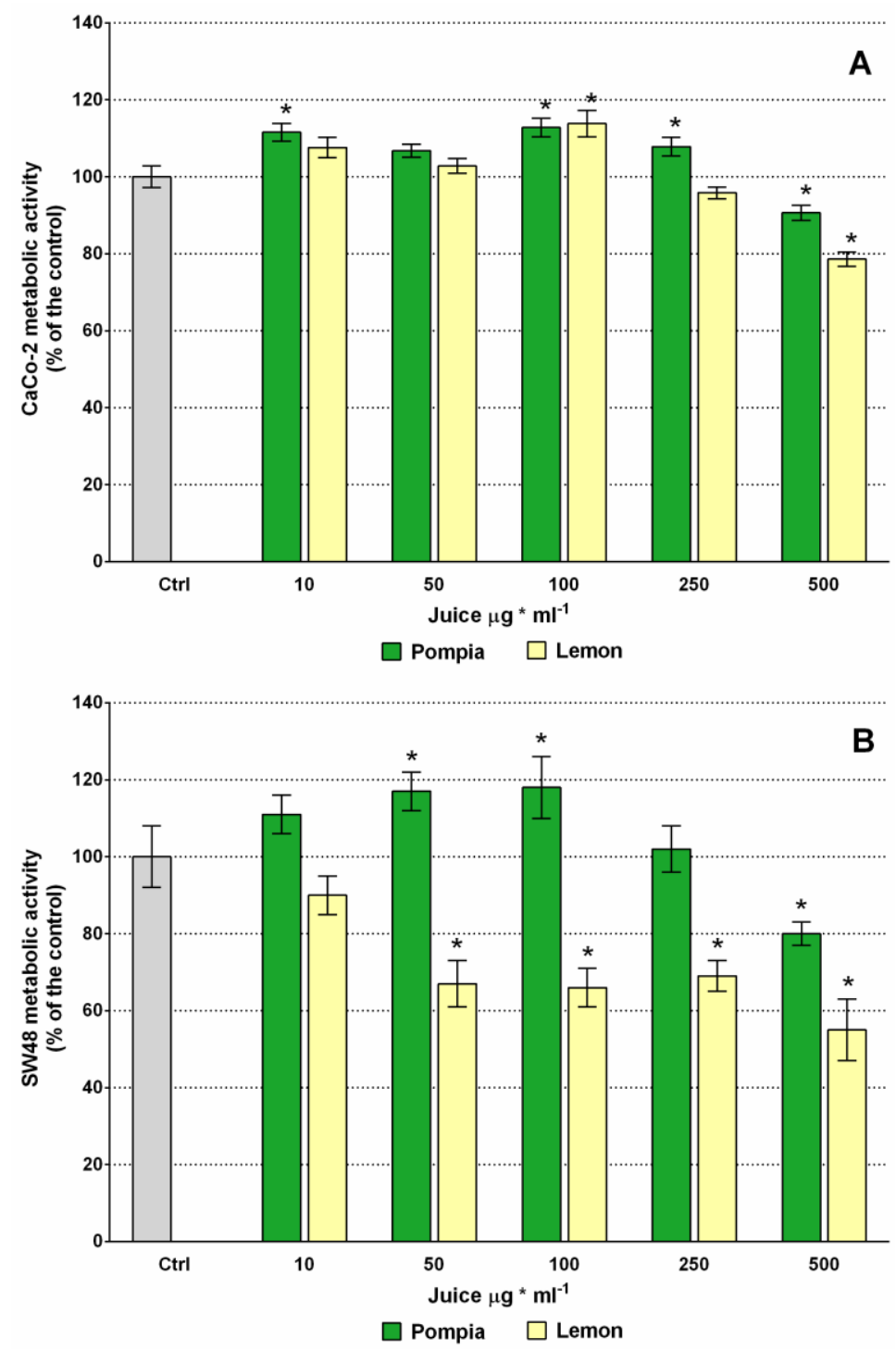

Figure 3. Effect of Pompia and lemon juices on metabolic activity of parental undifferentiated CaCo-2 (A) and SW48 (B) colon cancer cell lines. ${ }^{*}=\mathrm{p} \leq 0.01$ vs control.

No significant difference against control was observed in the SW48 cells number (Figure S7B). Otherwise, the SW48 metabolic activity progressively increased when they were exposed to 10-50 and $100 \mu \mathrm{g} \mathrm{mL}{ }^{-1}$ of Pompia juice, then it rapidly decreased reaching the control values at $250 \mu \mathrm{g} \mathrm{mL}^{-1}$ and then it was reduced by $20 \%$ when the cells were treated with $500 \mu \mathrm{g} \mathrm{mL}^{-1}$ (Figure 3B). Lemon juice has proven to be much more aggressive toward SW 48 cells: $50 \mu \mathrm{g} \mathrm{mL}^{-1}$ reduced it by $30 \%$, up to a maximum of $50 \%$ at $500 \mu \mathrm{g} \mathrm{mL} \mathrm{m}^{-1}$.

The effects of natural compounds on cancer cells viability can vary depending on cell types, and the mechanisms involved in cellular responses are still largely unknown. In this paper, dose-dependent antioxidant and anti-proliferative effects were observed, in accordance with previous studies with other natural compounds. As already reported [41-43] the consumption of citrus juice and their phytochemicals plays an important role in the prevention and treatment of various cancers, including colon cancer. Moreover, their greater or lesser effect related to the tumor staging should not surprise [41]. Our treatments with low doses of Pompia and lemon had different effects on both colon cancer cell lines, showing a greater effect on SW48, cells with metastatic capacity. Other authors obtained similar 
data with bergamot juice but with ten times higher doses [13,44]. Moreover, the treatment with low concentration of Pompia juice ( $\leq 100 \mu \mathrm{g} \mathrm{mL}^{-1}$ ) increased the number of $\mathrm{CaCo} 2$ cells and the metabolic activity of $\mathrm{CaCo} 2$ and SW48. Even though it was similarly reported [44], we do not have any definite explanation for this effect, which would deserve extra investigations. Further studies on neuroblastoma cells showed that bergamot juice significantly affected SK-N-SH and Lan-1 cell proliferation in vitro starting from $48 \mathrm{~h}$ of treatment [13]. Studies on human hepatocellular carcinoma showed that the growth rate of HepG2 cells is reduced by high concentrations of bergamot juice by the activation of apoptotic pathways [14]. The induction of apoptosis of Panc-28 cells, demonstrated by a high ratio $\mathrm{Bax} / \mathrm{Bcl}-2$, is the mechanism underlying the proliferation inhibitory capacity of Mexican lime against pancreatic cancer [16].

\subsection{Antimicrobial Assays}

The result of Kirby-Bauer diffusion procedure preliminary test is reported in Table 3. It indicates that orange juices were ineffective (data not shown) and that Pompia and lemon juices showed similar antibacterial activity: they inhibited Gram-positive strains Streptococcus aureus DSM1104 and E. faecalis DSM 2570 and, the most important, they exerted a strong inhibiting action on the nosocomial infection-associated pathogen, P. aeruginosa (Gram-negative). E. coli and K pneumoniae resulted not sensitive to citrus juices.

Table 3. Antimicrobial profile for Pompia and lemon juices $\left(4 \mathrm{mg} \mathrm{mL}^{-1}\right)$ with a set of Gram-positive and Gram-negative bacteria.

\begin{tabular}{cccc}
\hline Strain & Pompia & Lemon & Control \\
\hline Gram negative & & & \\
E. coli DSM 1103 & $0.0 \pm 0.0$ & $0.0 \pm 0.0$ & Amp. $19.6 \pm 0.7$ \\
$\begin{array}{c}\text { P. aeruginosa DSM 1117 } \\
\text { K. pneumoniae DSM 681 }\end{array}$ & $9.1 \pm 0.8$ & $7.8 \pm 1.4$ & Rif. $12.1 \pm 0.5$ \\
Gram positive & $0.0 \pm 0.0$ & $0.0 \pm 0.0$ & Amp. $9.5 \pm 0.8$ \\
S. aureus DSM 1104 & $10.9 \pm 1.1$ & $10.2 \pm 0.8$ & \\
E. faecalis DSM 2570 & $11.2 \pm 1.6$ & $11.4 \pm 2.2$ & Ox. $22.6 \pm 1.5$ \\
\hline
\end{tabular}

Legend: Amp = ampicillin; Ox = oxacillin; Rif = rifampin.

MIC, MBC, and Antibiofilm Activity (MBIC) Evaluation of Citrus Juices

According to Kirby-Bauer method, only the strains sensitive to citrus juices were used for MIC and MBC tests. As reported in Table 4, these juices caused bacterial growth inhibition (MIC) in a concentration range from 2 to $4 \mathrm{mg} \mathrm{mL}^{-1}$ : S. aureus represented the most citrus-sensitive strain. For all tested bacteria, both juices were unable to reveal a bactericidal effect inside the tried concentrations range (MBC $\left.>4 \mu \mathrm{g} \mu \mathrm{L}^{-1}\right)$.

Table 4. MIC, MBC, and MBIC values observed in selected Gram-positive and Gram-negative bacteria.

\begin{tabular}{lcccccc}
\hline \multicolumn{1}{c}{ Strain } & \multicolumn{3}{c}{ Lemon } & \multicolumn{3}{c}{ Pompia } \\
\hline & MIC & MBC & MBIC & MIC & MBC & MBIC \\
\cline { 2 - 7 } & & mg mL $^{-\mathbf{1}}$ & & & mg mL $^{-1}$ \\
\hline P. aeruginosa DSM 1117 & 4 & $>4$ & 4 & 4 & $>4$ & 2 \\
S. aureus DSM 1104 & 2 & $>4$ & 2 & 2 & $>4$ & 1 \\
E. faecalis DSM 2570 & 4 & $>4$ & 4 & 4 & $>4$ & 2 \\
\hline
\end{tabular}

Table 4 also reports the minimum biofilm inhibition concentration between Pompia and lemon juices. A significant difference between the two juices on the ability to interfere in the biofilm formation was observed. As shown in Table 4, Pompia juice reported lower MBIC values $\left(1 \log _{2}\right)$ than lemon. 
These results demonstrated that Pompia and lemon juices have an inhibitory effect against some pathogenic bacteria. Previous studies had already shown that Pompia rind extracts and lemon juice inhibited bacterial proliferation [11,23,24,45]. Although in this work Pompia and lemon juices did not show any bactericide activity, a bacterial growth inhibition and an antibiofilm effect have been observed. In this context, the antibiofilm propriety could be interesting since these microbial species are frequently associated with "biofilm-related diseases" in humans [46-48]; in in vitro experiments, as well as in the clinical practice, the microbial sessile status is often more resistant to conventional biocides and the host immune system, than their planktonic form [49]. For this reason, these infections are difficult to treat and could considerably rise the healthcare costs, as reported by several studies [50] and a "natural drug" able to inhibit the biofilm formation is highly sought.

\section{Materials and Methods}

\subsection{Fruit Samples and Juice Preparation}

Pompia (Citrus limon var. pompia Camarda var. nova), lemon (Citrus limon (L.) Burm. f.) cultivar Lisbon, and orange (Citrus sinensis (L.) Osbek) cultivars Hamlin, Sanguinello, and Moro, were hand-harvested from December 2018 to February 2019, when commercially mature, in the experimental orchard of the Institute of Sciences of Food Production, in Oristano (Latitude: $39^{\circ} 53^{\prime} 58.45^{\prime \prime}$ N; Longitude: $8^{\circ} 35^{\prime} 35.74^{\prime \prime}$ E; $8 \mathrm{~m}$ a.s.1.) Sardinia, in Italy. Fruit was delivered to the laboratories immediately after harvest. There, medium size fruits, free from rind defects were randomly selected, placed in plastic trays, and left overnight at $17^{\circ} \mathrm{C}$. The juice prepared by squeezing fresh fruits, was filtered with a kitchen strainer, immediately stored in ultra-freezer at $-80{ }^{\circ} \mathrm{C}$, and then lyophilized. Freeze dried samples were fully rehydrated immediately before chemical analyses, phenolics detection, and quantification, in vitro calibrations and antioxidant activity determination. For biological tests, dried juices were dissolved in PBS and then diluted with the specific medium.

\subsection{Chemicals and Cell Lines}

All the reagents and solvents were of reagent grade, used without any further purification. Ascorbic acid (AA), ascorbate oxidase (AOx, EC 1.10.3.3), 2,2-diphenyl-1-picrylhydrazyl (DPPH) free radical, Rutin, 2,2'-Azino-bis(3-ethylbenzothiazoline-6-sulfonic acid, diammonium salt (ABTS), 2' ,7'dichlorodihydrofluorescein diacetate $\left(\mathrm{H}_{2} \mathrm{DCFDA}\right)$, tert-butyl hydroperoxide $(\mathrm{TBH})$, trichloroacetic acid (TCA), 2-thiobarbituric acid (TBA), methanol, 1,1,3,3-tetraethoxypropane (TEP), thiazolyl blue tetrazolium bromide (MTT), isopropanol, streptomycin, penicillin, ampicillin, oxacillin, cloxacillin, rifampicin, oxytetracycline, and L-glutamine were purchased from Sigma-Aldrich (Milan, Italy). The phosphate-buffered saline (PBS) solution was made using $\mathrm{NaCl}(137 \mathrm{mM}), \mathrm{NaOH}(2.7 \mathrm{mM}), \mathrm{Na}_{2} \mathrm{HPO}_{4}$ $(8.1 \mathrm{mM})$, and $\mathrm{KH}_{2} \mathrm{PO}_{4}(1.47 \mathrm{mM})$ from Sigma and then adjusted to $\mathrm{pH}$ 7.4. Dulbecco's modified Eagle's medium (DMEM), RPMI 1640 and fetal bovine serum (FBS) were purchased from Euroclone S.p.A. (Pero, Milan, Italy).

CaCo-2 cells were obtained from the European Collection of Cell Cultures (ECACC, Salisbury, UK). SW48 were purchased from the American Type Culture Collection (ATCC, LGC Standards S.r.l., Milan, Italy).

\subsection{Chemical Analyses}

pH was measured by a pH-meter (Orion, 420A, Champaign, IL, USA). Titratable acidity (TA) was determined by Mettler Toledo ${ }^{\mathrm{TM}}$ DL15 Potentiometric Titrator (Milano, Italy) and expressed as percentage of citric acid equivalents. Total soluble solids (TSS) were determined by a digital refractometer Atago PR-101 (Atago, Tokyo, Japan) at $20^{\circ} \mathrm{C}$ and expressed as Brix. 


\subsection{Phenolic Characterization of Citrus Juices}

Separations of phenolic compounds were performed using a 1200 series HPLC liquid chromatographic system (Agilent Technologies, Milano, Italy). A Phenomenex Kinetex C18 column $(100 \mathrm{~mm} \times 2.1 \mathrm{~mm}, 2.6 \mu \mathrm{m}, 100 \AA$, Milano, Italy) was used for the chromatographic separation. The flow rate was $0.250 \mathrm{~mL} / \mathrm{min}$ during a $60-\mathrm{min}$ period with an injection volume of $5 \mu \mathrm{l}$. Mobile phases were: $1 \mathrm{mM}$ ammonium acetate with $0.1 \%$ acetic acid (A) and methanol with $0.1 \%$ acetic acid (B). A linear gradient elution of solvents was applied with the following program: $0 \mathrm{~min}, 85 \%$ B; $20 \mathrm{~min}, 75 \% \mathrm{~B}, 40 \mathrm{~min} 50 \% \mathrm{~B}, 50 \mathrm{~min} 30 \% \mathrm{~B}$. The column was equilibrated for $8 \mathrm{~min}$ prior to each analysis. The chromatographic system was coupled to an OrbiTrap high resolution mass spectrometer (Waltham, MA, USA) equipped with heated electrospray ionization probe HESI-II (Thermo Scientific, Bremen, Germany) operating in both positive and negative ion mode. Parameters of the ion source were as follows: spray voltage, $3.0 \mathrm{kV}$ (positive ionization), $2.5 \mathrm{kV}$ (negative ionization); sheath gas flow rate $\left(\mathrm{N}_{2}\right) 35$ units; capillary temperature $300{ }^{\circ} \mathrm{C}$; S-lens RF level 50; heater temperature $350{ }^{\circ} \mathrm{C}$. Full MS acquisition was performed with resolution power 70000 FWHM with mass accuracy of $5 \mathrm{ppm}$. The MS parameters were: AGC target $3 \mathrm{e}^{6}$, maximum injection time (IT) $200 \mathrm{~ms}$, and scan range 100-1500 m/z. The Xcalibur ${ }^{\mathrm{TM}}$ software (software version 4.3, Thermo Scientific, Bremen, Germany) was used to control the instruments and to process the data. Mass deviation were calculated as parts per million [(calculated mass-experimental mass/calculated mass)] and were found to be below $5 \mathrm{ppm}$.

Peaks of the phenolic compounds were characterized on the basis of their retention time $\left(t_{R}\right)$ values, UV/Vis spectra, and HRMS spectra. Individual phenolic compounds were quantified using calibration curves of the respective reference compounds detected by DAD (Agilent, Santa Clara, CA, USA) at 270 and $320 \mathrm{~nm}$.

\subsection{Analytical and Biological Determination of Antioxidant Properties of Pompia and Other Citrus Juices}

The antioxidant properties of Pompia and other citrus juices were investigated by both analytical and biological tests.

\subsubsection{Analytical Detection of Antioxidant Activity and AA Content}

The antioxidant capacity was evaluated by both a non-spectrophotometric and a spectrophotometric technique, since methods based on color changes of chromogen radicals could be influenced by the presence of red pigments (anthocyanins) in the juice of blood oranges (Moro and Sanguinello). The capacity of the tested samples to scavenge the DPPH radical was determined by electron paramagnetic spectroscopy (EPR) according to [51] with some modifications, and results were expressed as mmoles equivalents of $\mathrm{AA} \mathrm{L}^{-1}$ of juice on the basis of a calibration curve $\left(\mathrm{r}^{2}=0.99\right)$; second, the ABTS radical cation decolorization assay was performed according to [52] and the antiradical activity was expressed as mmoles equivalents of $\mathrm{AA} \mathrm{L}^{-1}$ of juice. AA was detected by titrimetric and chromatographic methods and expressed as $\mathrm{mg} \mathrm{L}^{-1}$ of juice [7].

\subsubsection{Electrochemical Determination of the Contribution of AA and Phenolics to Antioxidant Capacity}

Amperometry and cyclic voltammetry $(\mathrm{CV})$ were used to determine the contribution of AA and phenolics to antioxidant activity. A previously developed fullerene $\mathrm{C}_{60}$-nanostructured sensor/biosensor system (SB), based on ascorbate oxidase (AOx) enzyme [26,53], was used to simultaneously determine the antioxidant activity and the AA content of all fruit juices, by distinguishing between AA and phenolics contribution to antioxidant capacity. An exhaustive description of the SB and its working principle is reported in [7] and [26]. All electrochemical measures were performed using a four-channel system (eDAQ Quadstat, e-Corder 410, and Echem software, eDAQ Europe, Warszawa, Poland) placing the SB in a cell, a glass beaker containing $20 \mathrm{~mL}$ of air-bubbled PBS at pH 5.6 which is the optimal $\mathrm{pH}$ for the AOx activity. The SB system operated at a constant applied potential ( $\left.\mathrm{E}_{\mathrm{app}}\right)$ of $+500 \mathrm{mV}$ (vs. carbon pseudo-reference electrode), a value that, according to [54], enables to determine 
the antioxidant capacity of phenolics, sugars, organic acids and, in general, of any molecule that can be oxidized at this specific potential. All the molecules with a redox potential higher than $+500 \mathrm{mV}$ were not accounted for. The quantification of AA and antioxidant capacity was obtained by injecting $100 \mu \mathrm{L}$ of citrus juice into a $20 \mathrm{~mL}$ PBS solution. The recorded currents were plotted on an AA calibration curve, with concentrations ranging between 0 and $100 \mu \mathrm{M}$, and converted to express the values of antioxidant capacity as mmoles equivalents of $\mathrm{AA} \mathrm{L}^{-1}$ of juice and $\mathrm{AA}$ content as $\mathrm{mg} \mathrm{L}^{-1}$ of juice.

Moreover, $\mathrm{CVs}$ were carried out in order to investigate the electrochemical behavior of fruit juices, at the WE surface vs. the $\mathrm{Ag} / \mathrm{AgCl}$ Ref, at a scan rate of $100 \mathrm{mV}$. CVs were executed from $-200 \mathrm{mV}$ to $+800 \mathrm{mV}$. CVs of the most represented phenolics were carried out from $-1 \mathrm{~V}$ to $+1 \mathrm{~V}$.

3.5.3. Evaluation of Protective Effect of Pompia and Other Citrus Juices Against ROS and the Enterocytes Membrane Damage

Biological assays were performed to study the protective effect of citrus juices against ROS and the enterocytes membrane damage. Caco- 2 cells, at passage 45-60, were plated at a density of about $1 \times 10^{5} \mathrm{~mL}^{-1}$ and used 21 days post seeding. Once differentiated, Caco- 2 cells acquire morphological and functional characteristics of mature enterocytes [55]. Differentiated CaCo-2 cells grew in Dulbecco's modified Eagle's medium (DMEM), supplemented with $2.5 \%$ of heat-inactivated fetal bovine serum (FBS), $100 \mathrm{U} \mathrm{mL}^{-1}$ penicillin and $100 \mu \mathrm{g} \mathrm{mL}{ }^{-1}$ streptomycin, at $37^{\circ} \mathrm{C}$ under a humidified atmosphere of $95 \%$ air and $5 \% \mathrm{CO}_{2}$.

\section{Evaluation of Potential Toxic Activity of Citrus Juices}

An MTT assay was performed using differentiated Caco-2 cells [56], in order to evaluate any toxic activity of tested juices. Cells were seeded in 96 -well plates $\left(5 \times 10^{4}\right.$ viable cells $\mathrm{mL}^{-1}$ in $\left.100 \mu \mathrm{L}\right)$, exposed to various concentrations of juices between 10 and $500 \mu \mathrm{g} \mathrm{mL}^{-1}$ in medium, and incubated for $72 \mathrm{~h}$. After incubation, the medium was removed and $100 \mu \mathrm{L}$ of MTT solution $\left(5 \mathrm{mg} \mathrm{mL}^{-1}\right.$ of fresh medium) was added and left at $37^{\circ} \mathrm{C}$ for $6 \mathrm{~h}$. The medium was then aspirated, $100 \mu \mathrm{L}$ of dimethyl sulfoxide (DMSO) was added in each well, and the absorbance was read at $570 \mathrm{~nm}$ by a Tecan micro plate reader (Infinite 200, Salzburg, Austria). Percentage of cell growth was calculated by normalizing the absorbance of treated cells to corresponding control.

\section{Determination of Intracellular ROS Production and MDA Level}

Intracellular ROS production was monitored in differentiated CaCo-2 cells seeded in 96-well plates [37]. The old culture medium was removed, cells were washed with $200 \mu \mathrm{L}$ of PBS and incubated for $30 \mathrm{~min}$ in PBS with $10 \mu \mathrm{M}$ of $\mathrm{H}_{2}$ DCFDA. $\mathrm{H}_{2}$ DCFDA was then removed, the cells were treated with juices at concentration ranging from 10 to $500 \mu \mathrm{g} \mathrm{mL}^{-1}$ and, 30 min later, with a $2.5 \mathrm{mM} \mathrm{TBH}$ aqueous solution. ROS production was monitored by reading the fluorescence emitted after $120 \mathrm{~min}$ of incubation, using a Tecan micro plate reader at a controlled temperature of $37^{\circ} \mathrm{C}$. The reading was performed using an excitation of $490 \mathrm{~nm}$ and an emission of $520 \mathrm{~nm}$. After $120 \mathrm{~min}$ the supernatant was collected and malonyldialdehyde (MDA) level was measured with the TBARS test with HPLC quantification, as previously described [57]. Briefly, $100 \mu \mathrm{L}$ of $10 \%$ TCA was added to $400 \mu \mathrm{L}$ of PBS supernatant in a microcentrifuge tube; samples were mixed and left at room temperature. After $20 \mathrm{~min}$, $200 \mu \mathrm{L}$ of $0.6 \%$ TBA was added; the samples were incubated at $90^{\circ} \mathrm{C}$ for $45 \mathrm{~min}$ and then centrifuged at $5000 \mathrm{~g}$ for $15 \mathrm{~min}$ at $4{ }^{\circ} \mathrm{C}$. Aliquots of the supernatant were injected into an Agilent 1100 HPLC system equipped with a diode-array detector (HPLC-DAD) and analysis was carried out using a Varian (Middelburg, The Netherlands) column, Inertsil 5 ODS-2, $150 \times 4.6 \mathrm{~mm}$; the mobile phase was a mixture of $\mathrm{KH}_{2} \mathrm{PO}_{4} 50 \mathrm{mM} \mathrm{pH} 7 / \mathrm{MeOH}(65 / 35, v / v)$ at a flow rate of $1 \mathrm{~mL} \mathrm{~min}^{-1}$. The adduct MDA-TBA was revealed at $532 \mathrm{~nm}$. A standard curve was prepared with the samples using a TEP solution in PBS $\left(0.05-10 \mu \mathrm{M} ; \mathrm{r}^{2}=0.99\right)$. 


\subsection{Evaluation of Citrus Juices Effect on Cancer Cells Metabolic Activity}

Undifferentiated $\mathrm{CaCo}-2$ and SW48 colon cancer cells were used to study the effect of citrus juices on cancer cells metabolic activity. Undifferentiated $\mathrm{CaCo} 2$ were grown in DMEM, containing $10 \%$ FBS, $1 \%$ penicillin $\left(100 \mathrm{U} \mathrm{mL}^{-1}\right) /$ streptomycin $\left(100 \mu \mathrm{g} \mathrm{mL}^{-1}\right)$, and $1 \% \mathrm{~L}$-glutamine at $37^{\circ} \mathrm{C}$ under humidified 5\% $\mathrm{CO}_{2} /$ air. For experimental studies, cells at passage 25-30 were plated at a density of about $5 \times 10^{4} \mathrm{~mL}^{-1}$ and used $24 \mathrm{~h}$ post seeding.

SW48 cell lines were grown in RPMI 1640 medium, containing 10\% FBS, 1\% penicillin $\left(100 \mathrm{U} \mathrm{mL}^{-1}\right) /$ streptomycin $\left(100 \mu \mathrm{g} \mathrm{mL} \mathrm{m}^{-1}\right)$, and $1 \% \mathrm{~L}$-glutamine at $37^{\circ} \mathrm{C}$ under humidified $5 \% \mathrm{CO}_{2} /$ air. For experimental studies, cells at passage 7-10 were plated at a density of about $1 \times 10^{5} \mathrm{~mL}^{-1}$ and used $24 \mathrm{~h}$ post seeding.

Cells were first exposed to increasing concentrations of juice $\left(10-500 \mu \mathrm{g} \mathrm{mL}{ }^{-1}\right)$ for $24 \mathrm{~h} . \mathrm{CaCo}_{2}$ and SW48 cell number was evaluated using the crystal violet staining assay (CVS) as described by [58]: cells were fixed for $20 \mathrm{~min}$ at room temperature with $4 \%$ paraformaldehyde (PFA), stained with $0.1 \%$ crystal violet in $20 \%$ methanol for 20 min, washed with PBS, solubilized with $10 \%$ acetic acid, and read at $595 \mathrm{~nm}$ in a Beauty Diagnostic microplate reader.

The MTT assay was used to assess the metabolic activity as previously reported [40]: cells were incubated with $100 \mu \mathrm{L}\left(0.05 \mathrm{mg} \mathrm{mL}^{-1}\right)$ of MTT, and the cultures were allowed to incubate at $37^{\circ} \mathrm{C}$ for $3 \mathrm{~h}$. The MTT was removed and the formazan crystals were dissolved in $100 \mu \mathrm{L}$ of isopropanol. The color was read at $570 \mathrm{~nm}$ using a microplate reader (Sunrise ${ }^{\mathrm{TM}}$ Absorbance Reader-TECAN).

Percentage of cell growth and metabolic activity were calculated by normalizing the absorbance of the treated cells to corresponding control.

\subsection{Antimicrobial Activity}

The antimicrobial activity of citrus juices was evaluated as already reported [59]. All bacterial strains Escherichia coli DSM 1103, Pseudomonas aeruginosa DSM 1117, Klebsiella pneumoniae DSM 681, Streptococcus aureus DSM 1104, and Enterococcus faecalis DSM 2570 were purchased from DSMZ (German Collection of Microorganism and Cell Cultures, Braunschweig, Germany). Fifty microliters of the frozen bacterial suspension was inoculated in Mueller Hinton and Schaedler Broth (Microbiol, Uta, Cagliari, Italy) and incubated at $37{ }^{\circ} \mathrm{C}$ until the growth middle-logarithmic phase; E. faecalis was inoculated in Schaedler Broth and incubated at $37^{\circ} \mathrm{C}$ with $5 \% \mathrm{CO}_{2}$.

A preliminary evaluation of all juices was performed by Kirby-Bauer disk-diffusion modified method [60]. Briefly, $15 \mathrm{~mL}$ of agarized Muller Hinton or Schaedler medium (Microbiol) at $55^{\circ} \mathrm{C}$ were added to a $90 \varnothing \mathrm{mm}$ Petri dish. Prior to agar solidification, four sterile iron rivets $(\varnothing 10 \mathrm{~mm}$ diameter and $2 \mathrm{~mm}$ thick) were put into the agar mixture so that, once removed from the solidified agar, they leave $100 \mu \mathrm{L}$ wells. A $5 \times 10^{7} \mathrm{CFU} \mathrm{mL} \mathrm{m}^{-1}$ standardized inoculum of each strain was inoculated onto the plate surface using a sterile swab, then $100 \mu \mathrm{L}$ of a $4 \mathrm{mg} \mathrm{L}^{-1}$ juice solution was added into each well. Reference antibiotic from Oxoid (Thermo Fisher Scientific IT, Milan, Italy) were used as specific positive controls: rifampicin (Rif) $30 \mu \mathrm{g} /$ disk, ampicillin (Amp) $10 \mu \mathrm{g} / \mathrm{disk}$, and oxacillin (Ox) $1 \mu \mathrm{g} / \mathrm{disk}$. The Petri dishes were incubated at $37^{\circ} \mathrm{C}$ for $24 \mathrm{~h}$. After incubation, the diameter of the inhibition halo was measured. The experiment was performed in triplicate. Three readings were recorded, as recommended by the EUCAST (http://www.eucast.org) and [61] procedures.

\subsubsection{Broth Dilution Tests, MIC, and MBC}

The minimum inhibitory concentration (MIC) and minimum bactericidal concentration (MBC) tests were performed according to EUCAST protocols, using the micro-broth dilution method with $\frac{1}{2}$ serial dilutions in liquid medium [62,63]. Concentration ranging from $4 \mathrm{mg} \mathrm{mL}^{-1}$ to $0.039 \mathrm{mg} \mathrm{mL}^{-1}$ for each citrus juice were tested. Each strain was inoculated in the exponential $(\log )$ phase with a final concentration corresponding to $1 \times 10^{6} \mathrm{CFU} \mathrm{mL}^{-1}$; the experiment was performed in triplicate and after $24 \mathrm{~h}$ of growth at $37^{\circ} \mathrm{C}$, the turbidity at $\lambda=620 \mathrm{~nm}$ of each set of combinations was measured. MIC 
was the lowest concentration that demonstrated bacteria growth inhibition, while MBC represented the lowest concentration able to reduce $99.9 \%$ of bacteria vitality $\left(\mathrm{CFU} \mathrm{mL}{ }^{-1}\right)$, when the microbial suspensions was plated in agar medium.

\subsubsection{Anti-Biofilm Assay}

Minimal biofilm inhibitory concentration (MBIC) for all citrus juices was evaluated following the modified crystal violet staining protocol described by Montana University Center for Biofilm Engineering (http://www.biofilm.montana.edu). In a multiwell plate containing $1 \times 10^{6} \mathrm{CFU} \mathrm{mL}^{-1} \mathrm{of}$ bacterial suspension, a serial concentration from 4 to $0.039 \mathrm{mg} \mathrm{mL}^{-1}$ of each citrus juice has been tested. Cultures were maintained at $37^{\circ} \mathrm{C}$ for 3 days. After incubation, the plates were washed three times with PBS, then the biofilm adhering to well surface was stained with a $0.4 \%$ crystal-violet solution for $2 \mathrm{~min}$. Following two washes with PBS, each well was added of $100 \mu \mathrm{l}$ of $30 \%$ acetic acid. The biofilm was measured by a colorimetric assay at $620 \mathrm{~nm}$ by Multiskan FC Microplate Photometer (Thermo Fisher Scientific IT, Milan). MBIC was the juice concentration reporting an absorbance comparable with negative control (wells without bacteria).

\subsection{Statistical Analysis}

Statistical analysis was performed by GraphPad Prism 5 for Windows software (GraphPad Software, Inc., La Jolla, CA 92037, USA). Phenolics and ascorbic acid content of juices were expressed as $\mathrm{mg} \mathrm{L}^{-1}$ of juice. Antioxidant activity was expressed as millimoles equivalents of ascorbic acid $\mathrm{L}^{-1}$ of juice. For analytical tests, a one-way ANOVA was performed to compare results obtained with different analytical methods, using a unifactorial complete randomized block design. Mean comparisons were calculated by Fisher's least significant difference test at $p \leq 0.05$.

Where not otherwise specified, biological tests were repeated four times. A one-way ANOVA was performed to highlight significant differences among treatments. The Student-Newman Keuls $(\mathrm{SNK})$ test was used to separate the mean values $(p \leq 0.01)$. Mean values \pm standard deviations (SD) are reported in figures.

For antimicrobial and antibiofilm assay, the evaluation of statistical significance of differences was performed using the Pearson's chi-square test by statistical calculator (https://www.socscistatistics. com/tests/); a significant level of $p<0.05$ was assumed.

\section{Conclusions}

In this paper some properties of Pompia juice were studied and compared with other commercially more widespread citrus species. Pompia juice was accurately characterized and new elements for a correct phylogeny were provided. The most represented flavonoids in the Pompia juice, are chrysoeriol-6,8-di-C-glucoside, isorhamnetin-7-rutinoside, diosmetin-6,8-dihexoside, and diosmin. Our characterization did not solve all existing doubts, but new analogies with lemon, citron, and bergamot have been found. Chemical analyzes highlighted the characteristics of a juice that is not drinkable as it is, but which instead possesses properties that suggest different uses. Analytical and electrochemical tests have shown a greater antioxidant capacity of Pompia than the other investigated species. It is mainly attributable to ascorbic acid and phenols with low redox potential with a specific significant contribution of isorhamnetin 3-O-rutinoside, a molecule with high reducing power, found in lemon in smaller quantities but not in orange juices. Biological assay demonstrated a lack of any apparent sign of systemic toxicity, and highlighted a strong effect against ROS and a significant capacity to protect cell membrane from ROS damages. Pompia juice, at very low concentration, also reduces the metabolic activity of colon cancer cell lines, although not as much as lemon, thus encouraging further insights. Finally, the results of tests on antimicrobial activity suggest that the analyzed juices have the ability to prevent the growth and formation of the biofilm of pathogenic microorganisms and that Pompia could be a raw material for obtaining natural antimicrobials. 
Although further studies are needed for a complete characterization of the biological activities of Pompia juice, our data, together with the existing literature on the fruit, constitute a scientific basis for the promotion of the traditional utilization of Pompia, and suggest to make a wider use of this species in the food or pharmaceutical field.

Supplementary Materials: The following are available online: Figure S1: HPLC DAD chromatograms of Pompia, lemon Lisbon, and oranges Hamlin, Sanguinello and Moro juices; Table S1. Characterization of phenolics and organic compounds of Pompia, Lemon ( $c v$ Lisbon) and orange ( $c v$ Hamlin, Sanguinello and Moro) juice by LCMS analysis; Figure S2. Cyclic voltammetry in the absence and in the presence of $1 \mathrm{mM}$ Isorhamnetin 3-O-rutinoside; Figure S3. Cyclic voltammetry in the absence and in the presence of $1 \mathrm{mM}$ Diosmin; Figure S4. Cyclic voltammetry in the absence and in the presence of $1 \mathrm{mM}$ Diosmetin 6,8-diglucoside; Figure S5. AA and quinic acid cyclic voltammetries; Figure S6. Cell viability of differentiated $\mathrm{CaCo}-2$ cells treated with Pompia, Lemon ( $c v$ Lisbon) and orange ( $c v$ Hamlin, Sanguinello and Moro) juice at concentrations between 10 and $500 \mu \mathrm{gL}^{-1}$ in medium, and incubated for 72 h; Figure S7. Effect of Pompia and lemon juices on cells number of CaCo-2 and SW48 colon cancer cell lines.

Author Contributions: A.B.: conceptualization and writing of the original draft, ascorbic acid and antioxidant capacity evaluation by electrochemical methods. Y.S. and G.D.: biological assays for antiproliferative properties of citrus juices on cancer cells. E.A.: phenolic characterization of citrus juices. A.F.: antioxidant capacity evaluation by DPPH and ABTS methods. P.A.S.: ascorbic acid and antioxidant capacity evaluation by electrochemical methods. M.P.: development of the methodology for biological assays. G.O. and A.S.: antimicrobial and antibiofilm assays. E.S.: conceptualization, coordination, general revision of the final manuscript version. D.S.: determination of antioxidant properties with spectrophotometric methods and data analysis and interpretation. M.D. and G.S.: conceptualization, antioxidant properties in cell cultures, data collection and analysis. All authors have read and agreed to the published version of the manuscript.

Funding: This research received no external funding.

Acknowledgments: The authors would like to thank Mrs. Gavina Serra for her technical assistance.

Conflicts of Interest: The authors declare no conflict of interest.

\section{References}

1. Tripoli, E.; Guardia, M.L.; Giammanco, S.; Majo, D.D.; Giammanco, M. Citrus flavonoids: Molecular structure, biological activity and nutritional properties: A review. Food Chem. 2007, 104, 466-479. [CrossRef]

2. Gironés-Vilaplana, A.; Moreno, D.A.; García-Viguera, C. Phytochemistry and biological activity of Spanish Citrus fruits. Food Funct. 2014, 5, 764-772. [CrossRef] [PubMed]

3. Nasri, H.; Baradaran, A.; Shirzad, H.; Rafieian-Kopaei, M. New concepts in nutraceuticals as alternative for pharmaceuticals. Int. J. Prev. Med. 2014, 5, 1487-1499. [PubMed]

4. Testai, L.; Calderone, V. Nutraceutical Value of Citrus Flavanones and Their Implications in Cardiovascular Disease. Nutrients 2017, 9, 502. [CrossRef]

5. Toh, J.Y.; Tan, V.M.H.; Lim, P.C.Y.; Lim, S.T.; Chong, M.F.F. Flavonoids from Fruit and Vegetables: A Focus on Cardiovascular Risk Factors. Curr. Atheroscler. Rep. 2013, 15, 368. [CrossRef]

6. Zou, Z.; Xi, W.; Hu, Y.; Nie, C.; Zhou, Z. Antioxidant activity of Citrus fruits. Food Chem. 2016, 196, 885-896. [CrossRef]

7. Barberis, A.; Spissu, Y.; Bazzu, G.; Fadda, A.; Azara, E.; Sanna, D.; Schirra, M.; Serra, P.A. Development and Characterization of an Ascorbate Oxidase-based Sensor-Biosensor System for Telemetric Detection of AA and Antioxidant Capacity in Fresh Orange Juice. Anal. Chem. 2014, 86, 8727-8734. [CrossRef]

8. Sommella, E.; Pepe, G.; Pagano, F.; Tenore, G.C.; Marzocco, S.; Manfra, M.; Calabrese, G.; Aquino, R.P.; Campiglia, P. UHPLC profiling and effects on LPS-stimulated J774A.1 macrophages of flavonoids from bergamot (Citrus bergamia) juice, an underestimated waste product with high anti-inflammatory potential. J. Funct. Foods 2014, 7, 641-649. [CrossRef]

9. Graziano, A.C.E.; Cardile, V.; Crascì, L.; Caggia, S.; Dugo, P.; Bonina, F.; Panico, A. Protective effects of an extract from Citrus bergamia against inflammatory injury in interferon-gamma and histamine exposed human keratinocytes. Life Sci. 2012, 90, 968-974. [CrossRef]

10. Mencherini, T.; Campone, L.; Piccinelli, A.L.; García Mesa, M.; Sánchez, D.M.; Aquino, R.P.; Rastrelli, L. HPLC-PDA-MS and NMR Characterization of a Hydroalcoholic Extract of Citrus aurantium L. var. amara Peel with Antiedematogenic Activity. J. Agric. Food Chem. 2013, 61, 1686-1693. [CrossRef] 
11. Otang, W.M.; Afolayan, A.J. Antimicrobial and antioxidant efficacy of Citrus limon L. peel extracts used for skin diseases by Xhosa tribe of Amathole District, Eastern Cape, South Africa. South Afr. J. Bot. 2016, 102, 46-49. [CrossRef]

12. Abirami, A.; Nagarani, G.; Siddhuraju, P. In vitro antioxidant, anti-diabetic, cholinesterase and tyrosinase inhibitory potential of fresh juice from Citrus hystrix and C. maxima fruits. Food Sci. Hum. Wellness 2014, 3, 16-25. [CrossRef]

13. Delle Monache, S.; Sanità, P.; Trapasso, E.; Ursino, M.R.; Dugo, P.; Russo, M.; Ferlazzo, N.; Calapai, G.; Angelucci, A.; Navarra, M. Correction: Mechanisms Underlying the Anti-Tumoral Effects of Citrus bergamia Juice. PLoS ONE 2018, 13, e0206630. [CrossRef] [PubMed]

14. Ferlazzo, N.; Cirmi, S.; Russo, M.; Trapasso, E.; Ursino, M.R.; Lombardo, G.E.; Gangemi, S.; Calapai, G.; Navarra, M. NF- $\mathrm{kB}$ mediates the antiproliferative and proapoptotic effects of bergamot juice in HepG2 cells. Life Sci. 2016, 146, 81-91. [CrossRef]

15. Navarra, M.; Mannucci, C.; Delbò, M.; Calapai, G. Citrus bergamia essential oil: From basic research to clinical application. Front. Pharmacol. 2015, 6, 36. [CrossRef] [PubMed]

16. Patil, J.R.; Chidambara Murthy, K.N.; Jayaprakasha, G.K.; Chetti, M.B.; Patil, B.S. Bioactive Compounds from Mexican Lime (Citrus aurantifolia) Juice Induce Apoptosis in Human Pancreatic Cells. J. Agric. Food Chem. 2009, 57, 10933-10942. [CrossRef]

17. Camarda, I.; Mazzola, P.; Brundu, A.; Fenu, G.; Lombardo, G.; Palla, F. Un agrume nella storia della Sardegna: Citrus limon var. pompia Camarda var. nova. Quad. Bot. Amb. Appl. 2013, 24, 109-118.

18. Fraternale, D.; Giamperi, L.; Bucchini, A.; Cara, P.; Ricci, D. In vitro Plant Regeneration from Callus of Citrus x monstruosa (Pompia), an Endemic Citrus of Sardinia. Nat. Prod. Commun. 2010, 5, 927-930. [CrossRef]

19. Luro, F.; Viglietti, G.; Marchi, E.; Costantino, G.; Scarpa, G.M.; Tomi, F.; Paoli, M.; Curk, F.; Ollitrault, P. Genetic, morphological and chemical investigations reveal the genetic origin of Pompia (C. medica tuberosa Risso \& Poiteau) - An old endemic Sardinian citrus fruit. Phytochemistry 2019, 168, 112083. [CrossRef]

20. Viglietti, G.; Galla, G.; Porceddu, A.; Barcaccia, G.; Curk, F.; Luro, F.; Scarpa, G.M. Karyological Analysis and DNA Barcoding of Pompia Citron: A First Step toward the Identification of Its Relatives. Plants (Baselswitzerland) 2019, 8, 83. [CrossRef]

21. Deiana, M.; Montoro, P.; Jerković, I.; Atzeri, A.; Marijanović, Z.; Serreli, G.; Piacente, S.; Tuberoso, C.I.G. First characterization of Pompia intrea candied fruit: The headspace chemical profile, polar extract composition and its biological activities. Food Res. Int. 2019, 120, 620-630. [CrossRef] [PubMed]

22. Manconi, M.; Manca, M.L.; Marongiu, F.; Caddeo, C.; Castangia, I.; Petretto, G.L.; Pintore, G.; Sarais, G.; D’hallewin, G.; Zaru, M.; et al. Chemical characterization of Citrus limon var. pompia and incorporation in phospholipid vesicles for skin delivery. Int. J. Pharm. 2016, 506, 449-457. [CrossRef] [PubMed]

23. Manconi, M.; Manca, M.L.; Caddeo, C.; Sarais, G.; Palmieri, A.; D’Hallewin, G.; Fadda, A.M. Citrus limon Extract Loaded in Vesicular Systems for the Protection of Oral Cavity. Medicines (Baselswitzerland) 2018, 5, 108. [CrossRef]

24. Fancello, F.; Petretto, G.L.; Zara, S.; Sanna, M.L.; Addis, R.; Maldini, M.; Foddai, M.; Rourke, J.P.; Chessa, M.; Pintore, G. Chemical characterization, antioxidant capacity and antimicrobial activity against food related microorganisms of Citrus limon var. pompia leaf essential oil. Lwt -Food Sci. Technol. 2016, 69, 579-585. [CrossRef]

25. Dongmo, P.M.J.; Tchoumbougnang, F.; Boyom, F.F.; Sonwa, E.T.; Zollo, P.H.A.; Menut, C. Antiradical, Antioxidant Activities and Anti-Inflammatory Potential of the Essential Oils of the Varieties of Citrus Limon and Citrus Aurantifolia Growing in Cameroon. J. Asian Sci. Res. 2013, 3, 1046-1057.

26. Barberis, A.; Spissu, Y.; Fadda, A.; Azara, E.; Bazzu, G.; Marceddu, S.; Angioni, A.; Sanna, D.; Schirra, M.; Serra, P.A. Simultaneous amperometric detection of ascorbic acid and antioxidant capacity in orange, blueberry and kiwi juice, by a telemetric system coupled with a fullerene- or nanotubes-modified ascorbate subtractive biosensor. Biosens. Bioelectron. 2015, 67, 214-223. [CrossRef] [PubMed]

27. Gil-Izquierdo, A.; Riquelme, M.T.; Porras, I.; Ferreres, F. Effect of the Rootstock and Interstock Grafted in Lemon Tree (Citrus limon (L.) Burm.) on the Flavonoid Content of Lemon Juice. J. Agric. Food Chem. 2004, 52, 324-331. [CrossRef]

28. Gattuso, G.; Barreca, D.; Gargiulli, C.; Leuzzi, U.; Caristi, C. Flavonoid Composition of Citrus Juices. Molecules 2007, 12, 1641-1673. [CrossRef] 
29. Khan, M.K.; Zill-E-Huma; Dangles, O. A comprehensive review on flavanones, the major citrus polyphenols. J. Food Compos. Anal. 2014, 33, 85-104. [CrossRef]

30. Zhao, P.; Duan, L.; Guo, L.; Dou, L.-L.; Dong, X.; Zhou, P.; Li, P.; Liu, E.-H. Chemical and biological comparison of the fruit extracts of Citrus wilsonii Tanaka and Citrus medica L. Food Chem. 2015, 173, 54-60. [CrossRef]

31. Costa, R.; Dugo, P.; Navarra, M.; Raymo, V.; Dugo, G.; Mondello, L. Study on the chemical composition variability of some processed bergamot (Citrus bergamia) essential oils. Flavour Fragr. J. 2010, 25, 4-12. [CrossRef]

32. Fadda, A.; Sanna, D. Advantages and pitfalls of the methods for the antioxidant activity evaluation. In Advances in Food Analysis Research; Haynes, A., Ed.; Nova Science Publishers: Hauppauge, NY, USA, 2015; pp. 65-88.

33. Barroso, M.F.; de-los-Santos-Álvarez, N.; Delerue-Matos, C.; Oliveira, M.B.P.P. Towards a reliable technology for antioxidant capacity and oxidative damage evaluation: Electrochemical (bio)sensors. Biosens. Bioelectron. 2011, 30, 1-12. [CrossRef] [PubMed]

34. Barberis, A.; Bazzu, G.; Calia, G.; Puggioni, G.M.G.; Rocchitta, G.G.; Migheli, R.; Schirra, M.; Desole, M.S.; Serra, P.A. New Ultralow-Cost Telemetric System for a Rapid Electrochemical Detection of Vitamin C in Fresh Orange Juice. Anal. Chem. 2010, 82, 5134-5140. [CrossRef] [PubMed]

35. Barreca, D.; Gattuso, G.; Laganà, G.; Leuzzi, U.; Bellocco, E. C- and O-glycosyl flavonoids in Sanguinello and Tarocco blood orange (Citrus sinensis (L.) Osbeck) juice: Identification and influence on antioxidant properties and acetylcholinesterase activity. Food Chem. 2016, 196, 619-627. [CrossRef]

36. Chamulitrat, W. Nitric Oxide Inhibited Peroxyl and Alkoxyl Radical Formation with Concomitant Protection against Oxidant Injury in Intestinal Epithelial Cells. Arch. Biochem. Biophys. 1998, 355, 206-214. [CrossRef]

37. Serreli, G.; Incani, A.; Atzeri, A.; Angioni, A.; Campus, M.; Cauli, E.; Zurru, R.; Deiana, M. Antioxidant Effect of Natural Table Olives Phenolic Extract Against Oxidative Stress and Membrane Damage in Enterocyte-Like Cells. J. Food Sci. 2017, 82, 380-385. [CrossRef]

38. Śliwka, L.; Wiktorska, K.; Suchocki, P.; Milczarek, M.; Mielczarek, S.; Lubelska, K.; Cierpiał, T.; Łyżwa, P.; Kiełbasiński, P.; Jaromin, A.; et al. The Comparison of MTT and CVS Assays for the Assessment of Anticancer Agent Interactions. PLoS ONE 2016, 11, e0155772. [CrossRef]

39. Surin, A.M.; Sharipov, R.R.; Krasil'nikova, I.A.; Boyarkin, D.P.; Lisina, O.Y.; Gorbacheva, L.R.; Avetisyan, A.V.; Pinelis, V.G. Disruption of functional activity of mitochondria during MTT assay of viability of cultured neurons. Biochem. (Mosc.) 2017, 82, 737-749. [CrossRef]

40. Posadino, A.M.; Cossu, A.; Giordo, R.; Zinellu, A.; Sotgia, S.; Vardeu, A.; Hoa, P.T.; Nguyen, L.H.V.; Carru, C.; Pintus, G. Resveratrol alters human endothelial cells redox state and causes mitochondrial-dependent cell death. Food Chem. Toxicol. 2015, 78, 10-16. [CrossRef]

41. Bradbury, K.E.; Appleby, P.N.; Key, T.J. Fruit, vegetable, and fiber intake in relation to cancer risk: Findings from the European Prospective Investigation into Cancer and Nutrition (EPIC). Am. J. Clin. Nutr. 2014, 100, 394S-398S. [CrossRef] [PubMed]

42. Mandalari, G.; Bisignano, C.; Cirmi, S.; Navarra, M. Effectiveness of Citrus Fruits on Helicobacter pylori. Evid. -Based Complementary Altern. Med. Ecam 2017, 2017, 8379262. [CrossRef]

43. Mao, Q.-Q.; Xu, X.-Y.; Shang, A.; Gan, R.-Y.; Wu, D.-T.; Atanasov, A.G.; Li, H.-B. Phytochemicals for the Prevention and Treatment of Gastric Cancer: Effects and Mechanisms. Int. J. Mol. Sci. 2020, $21,570$. [CrossRef] [PubMed]

44. Visalli, G.; Ferlazzo, N.; Cirmi, S.; Campiglia, P.; Gangemi, S.; Di Pietro, A.; Calapai, G.; Navarra, M. Bergamot Juice Extract Inhibits Proliferation by Inducing Apoptosis in Human Colon Cancer Cells. Anti-Cancer Agents Med. Chem. 2014, 14, 1402-1413. [CrossRef] [PubMed]

45. Hindi, N.K.K.; Chabuck, Z.A.G. Antimicrobial Activity of Different Aqueous Lemon Extracts. J. Appl. Pharm. Sci. 2013, 3, 74-78.

46. Boisvert, A.-A.; Cheng, M.P.; Sheppard, D.C.; Nguyen, D. Microbial Biofilms in Pulmonary and Critical Care Diseases. Ann. Am. Thorac. Soc. 2016, 13, 1615-1623. [CrossRef] [PubMed]

47. Del Pozo, J.L. Biofilm-related disease. Expert Rev. Anti-Infect. Ther. 2018, 16, 51-65. [CrossRef] [PubMed]

48. Subramenium, G.A.; Vijayakumar, K.; Pandian, S.K. Limonene inhibits streptococcal biofilm formation by targeting surface-associated virulence factors. J. Med. Microbiol. 2015, 64, 879-890. [CrossRef] 
49. Lim, S.Y.; Teh, C.S.J.; Thong, K.L. Biofilm-Related Diseases and Omics: Global Transcriptional Profiling of Enterococcus faecium Reveals Different Gene Expression Patterns in the Biofilm and Planktonic Cells. Omics: A J. Integr. Biol. 2017, 21, 592-602. [CrossRef]

50. Beikler, T.; Flemmig, T.F. Oral biofilm-associated diseases: Trends and implications for quality of life, systemic health and expenditures. Periodontology 2000 2011, 55, 87-103. [CrossRef]

51. Sanna, D.; Delogu, G.; Mulas, M.; Schirra, M.; Fadda, A. Determination of Free Radical Scavenging Activity of Plant Extracts Through DPPH Assay: An EPR and UV-Vis Study. Food Anal. Methods 2012, 5, 759-766. [CrossRef]

52. Re, R.; Pellegrini, N.; Proteggente, A.; Pannala, A.; Yang, M.; Rice-Evans, C. Antioxidant activity applying an improved ABTS radical cation decolorization assay. Free Radic. Biol. Med. 1999, 26, 1231-1237. [CrossRef]

53. Barberis, A.; Cefola, M.; Pace, B.; Azara, E.; Spissu, Y.; Serra, P.A.; Logrieco, A.F.; D’hallewin, G.; Fadda, A. Postharvest application of oxalic acid to preserve overall appearance and nutritional quality of fresh-cut green and purple asparagus during cold storage: A combined electrochemical and mass-spectrometry analysis approach. Postharvest Biol. Technol. 2019, 148, 158-167. [CrossRef]

54. Buratti, S.; Scampicchio, M.; Giovanelli, G.; Mannino, S. A low-cost and low-tech electrochemical flow system for the evaluation of total phenolic content and antioxidant power of tea infusions. Talanta 2008, 75, 312-316. [CrossRef]

55. Gonzales, G.B.; Van Camp, J.; Vissenaekens, H.; Raes, K.; Smagghe, G.; Grootaert, C. Review on the Use of Cell Cultures to Study Metabolism, Transport, and Accumulation of Flavonoids: From Mono-Cultures to Co-Culture Systems. Compr. Rev. Food Sci. Food Saf. 2015, 14, 741-754. [CrossRef]

56. Serreli, G.; Melis, M.P.; Corona, G.; Deiana, M. Modulation of LPS-induced nitric oxide production in intestinal cells by hydroxytyrosol and tyrosol metabolites: Insight into the mechanism of action. Food Chem. Toxicol. 2019, 125, 520-527. [CrossRef] [PubMed]

57. Incani, A.; Serra, G.; Atzeri, A.; Melis, M.P.; Serreli, G.; Bandino, G.; Sedda, P.; Campus, M.; Tuberoso, C.I.G.; Deiana, M. Extra virgin olive oil phenolic extracts counteract the pro-oxidant effect of dietary oxidized lipids in human intestinal cells. Food Chem. Toxicol. 2016, 90, 171-180. [CrossRef]

58. Pisano, M.; Pagnan, G.; Loi, M.; Mura, M.E.; Tilocca, M.G.; Palmieri, G.; Fabbri, D.; Dettori, M.A.; Delogu, G.; Ponzoni, M.; et al. Antiproliferative and pro-apoptotic activity of eugenol-related biphenyls on malignant melanoma cells. Mol. Cancer 2007, 6, 8. [CrossRef]

59. Erriu, M.; Pili, F.M.G.; Tuveri, E.; Pigliacampo, D.; Scano, A.; Montaldo, C.; Piras, V.; Denotti, G.; Pilloni, A.; Garau, V.; et al. Oil Essential Mouthwashes Antibacterial Activity against Aggregatibacter actinomycetemcomitans: A Comparison between Antibiofilm and Antiplanktonic Effects. Int. J. Dent. 2013, 2013, 164267. [CrossRef]

60. Orrù, G.; Demontis, C.; Mameli, A.; Tuveri, E.; Coni, P.; Pichiri, G.; Coghe, F.; Rosa, A.; Rossi, P.; D’hallewin, G. The Selective Interaction of Pistacia lentiscus Oil vs. Human Streptococci, an Old Functional Food Revisited with New Tools. Front. Microbiol. 2017, 8, 2067. [CrossRef]

61. Performance Standards for Antimicrobial Susceptibility Testing, 29th ed.; Clinical \& Laboratory Standards Institute (CLSI): Wayne, PA, USA, 2019; CLSI Supplement M100.

62. Langfield, R.D.; Scarano, F.J.; Heitzman, M.E.; Kondo, M.; Hammond, G.B.; Neto, C.C. Use of a modified microplate bioassay method to investigate antibacterial activity in the Peruvian medicinal plant Peperomia galioides. J. Ethnopharmacol. 2004, 94, 279-281. [CrossRef]

63. Wiegand, I.; Hilpert, K.; Hancock, R.E.W. Agar and broth dilution methods to determine the minimal inhibitory concentration (MIC) of antimicrobial substances. Nat. Protoc. 2008, 3, 163-175. [CrossRef] [PubMed]

Sample Availability: Samples of Pompia are available upon request, please contact the corresponding author. 